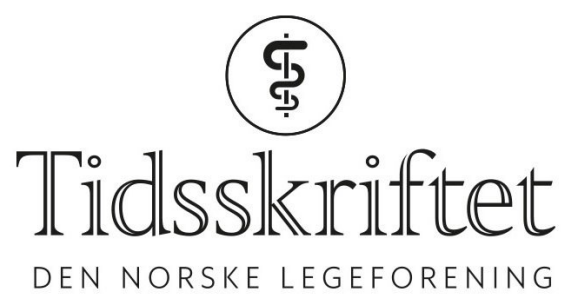

\title{
Taushet er død - hva hivaktivistene lærte oss
}

ESSAY

KETIL SLAGSTAD

Lege og medisinsk redaktør i Tidsskriftet

Hiv/aids-aktivismen i USA vokste frem som en reaksjon på diskriminerende tendenser i samfunnet generelt og håndteringen av epidemien spesielt. Aktivistenes arbeid fikk varige konsekvenser for biomedisinsk forskning. I en verden der konservative strømninger er i medvind, kan vi lære av aktivistenes fryktløshet. 


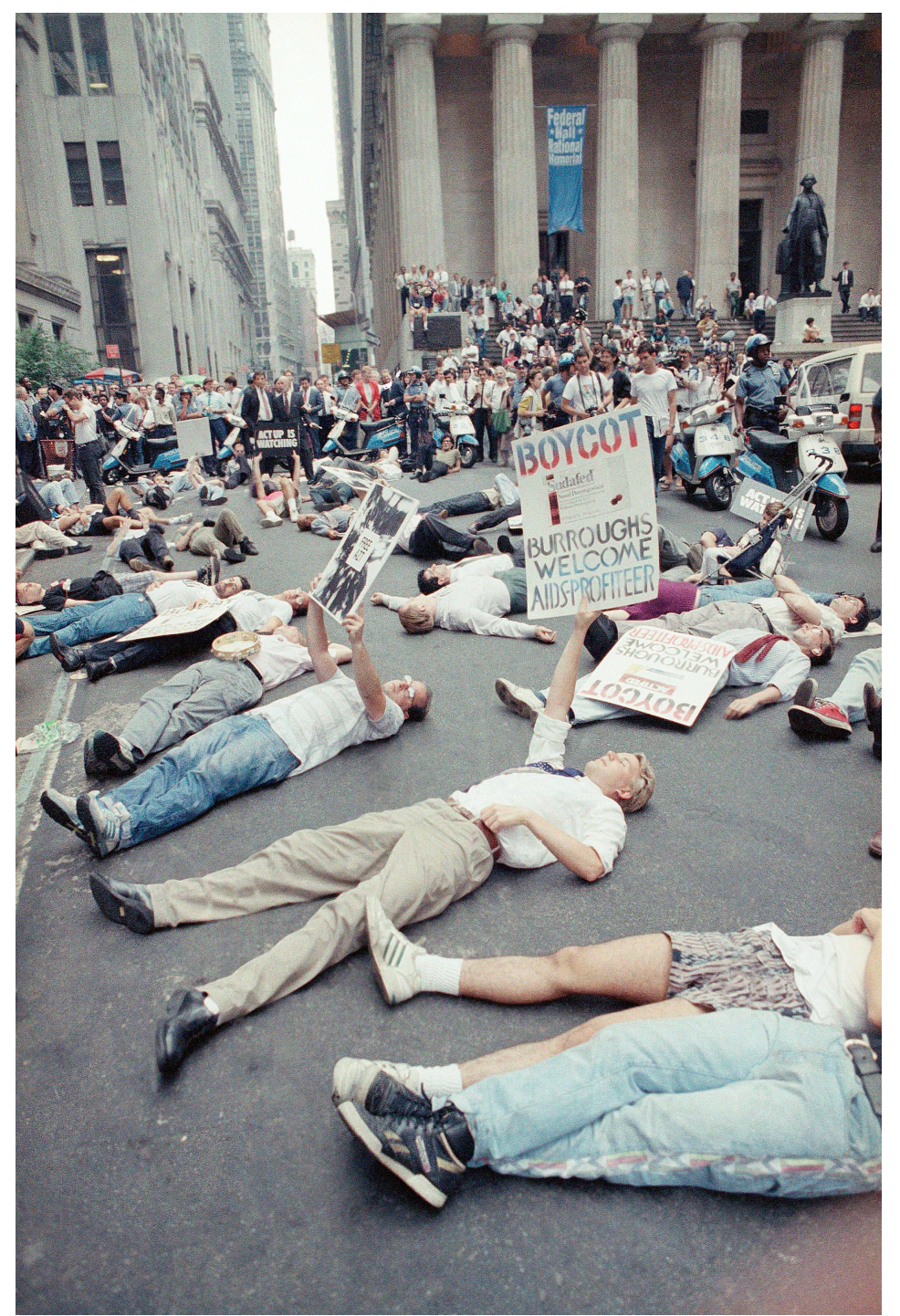

Aktivister demonstrerer mot høye legemiddelpriser på AZT foran New York-børsen 14. september 1989. Foto: AP/Tim Clary/NTB scanpix

Morgenen 14. september 1989 lurer Peter Staley seg inn i New York-børsen. Kledd som forretningsmenn med forfalskede besøksskilt kommer han og flere andre medlemmer i aktivistorganisasjonen ACT UP (AIDS Coalition to Unleash Power) seg til balkongen i bygningen, der de lenker seg fast med håndjern. Like før klokken halv ti, da børsen åpner, ruller de ut et banner påskrevet "SELL WELLCOME", med referanse til legemiddelselskapet Burroughs Wellcome, firmaet med patent på AZT (azidothymidine). Bjellen som vanligvis åpner børshandelen, blir overdøvet av aktivistenes håndholdte tåkelurer. Dermed blir handelen forsinket med flere minutter, unikt i børsens lange historie. Samtidig kaster aktivistene ut sedler påtrykt "We die while you make money. Fuck your profiteering".

Nesten 1500 demonstranter samler seg foran børsen, en demonstrasjon som var koordinert med tilsvarende protester i London og San Francisco. Mediedekningen er stor - med unntak av The New York Times som lenge valgte ikke å dekke aidsepidemien. Påfølgende dag kutter selskapet prisen på AZT. For ACT UP, organisasjonen som ble grunnlagt to år tidligere i 1987, er aksjonen en suksess. For Peter Staley er det også en personlig seier. Han hadde vendt tilbake til børsverdenen han en gang var en del av, men denne gangen som aktivist, frigjort åpent homofil og hivpositiv.

Scenen er hentet fra boken How to survive a plague, skrevet av David France, som kom ut i fjor. Forfatteren står også bak filmen med samme navn fra 2012. Forfatteren tar for seg hivepidemien i USA, fra de første tilfellene av aids i 1981 til effektiv behandling kom på markedet i midten av 9o-årene. Det er en personlig beretning om epidemien som rammet en hel generasjon homofile menn. Det er historien om hvordan friske personer, de fleste i 20- og 30-årene, fikk en dødsdom. Mange oppdaget sykdommen ved at det oppsto mørke 
flekker på huden. Ble ansiktet affisert, var det tydelig for alle at man var "en av dem” - en slags byllepestens tilbakekomst med hudlesjoner mettet med stigma og skam. Kaposis sarkom var også samfunnets første møte med sykdommen som i 1982 fikk betegnelsen aids. Rare cancer seen in 41 homosexuals lød artikkelen i The New York Times 3. juli 1981. Men også andre grupper ble rammet hardt, flere marginaliserte, for eksempel personer som injiserte rusmidler, transpersoner, personer med blødersykdommer og svarte.

\section{Moralsk fordømmelse}

På mange måter forsterket hivepidemien allerede eksisterende stigmatiserende tendenser $\mathrm{i}$ samfunnet i flere vestlige land, ikke bare i USA. I England fikk thatcherismen vann på mølla da en gruppe mennesker som hadde ikke-heteroseksuell sex ble rammet så eksplisitt. Blant konservative politikere var det stor motstand mot 196o- og 70-årenes liberale seksuelle revolusjon og kvinnefrigjøring, en utvikling som truet konservative verdier knyttet til kjernefamilie og kjønnsroller. Hivepidemien kunne brukes i denne kampen. "Uansvarlige”, seksuelt promiskuøse homser ble en enkel skyteskive. Som Kaye Wellings, professor ved London School of Hygiene and Tropical Medicine, har formulert det: "Vi bruker avvikere til å forsterke moralsk orden. (...) og det er her behovet for moralsk panikk kommer inn. (...) Da aids kom, var det som om det allerede hadde bygd seg opp et lager av undertrykt moral som måtte forløses. Aidsskremselen ble spredt nærmest bevisst. Alle sosiale institusjoner var involvert - pressen, rettsvesenet, til og med kirken.” (1).

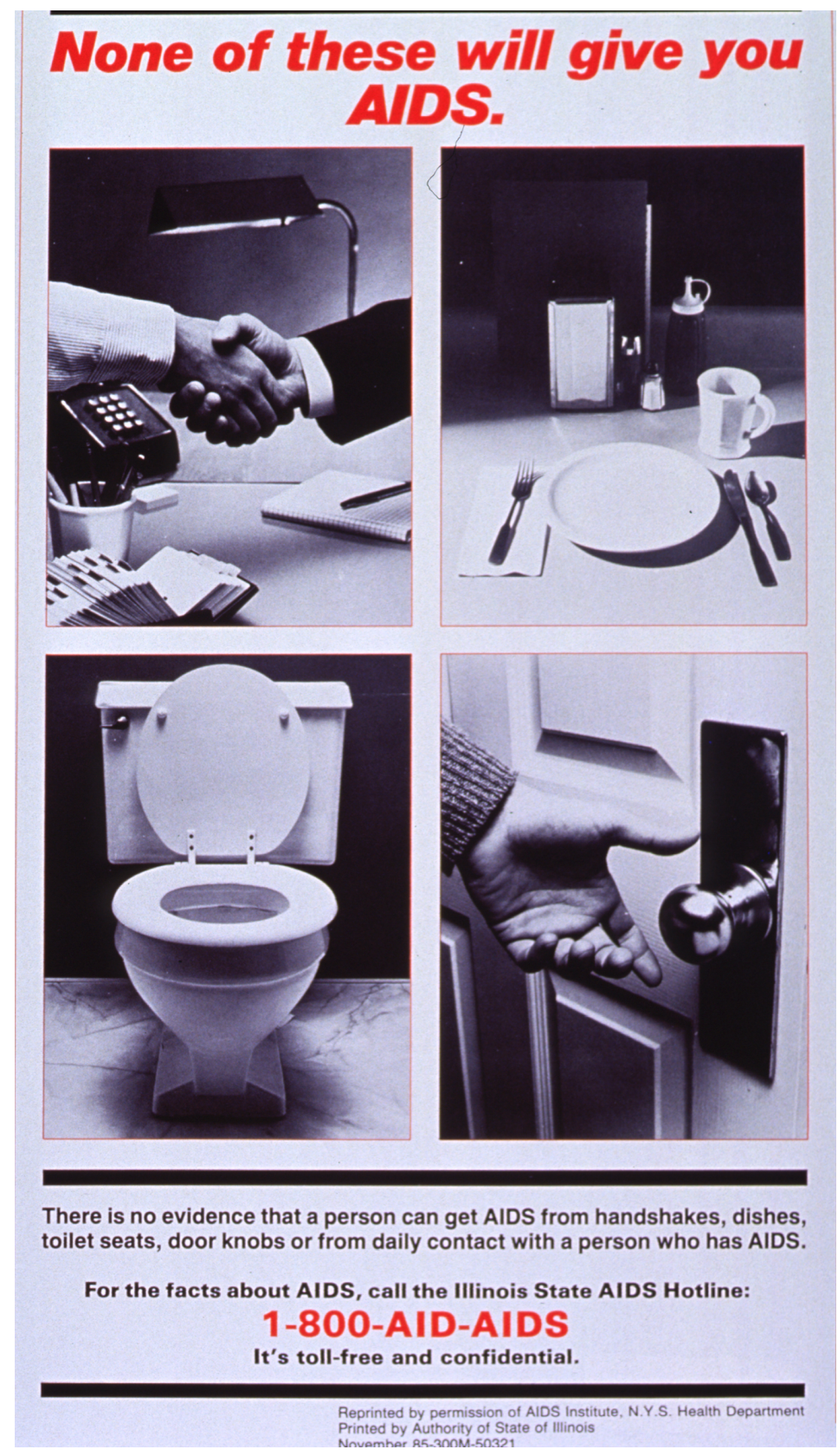


Offentlig informasjonskampanje fra 1987 hvor man eksplisitt forsøkte å berolige hysteri og fjerne stigma. Foto: Courtesy of the New York State Health Department

I Norge var det særlig kirken som moraliserte. For eksempel kalte en fremtredende biskop hiv for Guds straffedom, uten at kirken tok avstand fra uttalelsen. Det var ofte de mest konservative som fremmet de strengeste forslagene om tvangstiltak (2). Også utdelingen av rene sprøyter for å hindre hivspredning blant personer som injiserte rusmidler, var omstridt, både blant politikere og i politiet. Tiltaket ble sett på som et signal om at samfunnet aksepterte rusmidler.

\section{$\emptyset$ de-lagt homoliv}

I USA kom diskrimineringen til uttrykk på flere plan: Selv om The New York Times hadde vært tidlig ute med det nevnte oppslaget i 1981, tok det to år og nesten 6 oo døde før saken ble løftet frem på forsiden av avisen i 1983. Politikerne på sin side unnlot å sette epidemien på agendaen, unnlot å snakke offentlig om den og satte ikke av midler til å håndtere den. Det gjaldt for eksempel borgermesteren i New York, Ed Koch (1924-2013). France spekulerer i om Kochs singeltilværelse egentlig var uttrykk for at han selv var homofil, og at det kan forklare hans manglende håndtering av krisen. Og det gjaldt USAs president Ronald Reagan (1911-2004) som nevnte ordet “aids" offentlig for første gang i september 1985 - etter at mer enn 6 ooo mennesker var døde - mens visepresident George H. W. Bush ble kritisert for å fremme forslag om obligatorisk hivtesting. President Bill Clinton lovfestet i 1993 innreiseforbudet for utlendinger som var hivpositive.

Boken er også fortellingen om epidemien som endret en by. Rundt 100 ooo personer døde av aids i New York fra starten av epidemien til effektiv behandling ble gjort tilgjengelig. For homobevegelsen i 1960- og 70-årene ble fri sex brukt eksplisitt i frigjøringskampen fra et heteronormativt, sexistisk og patriarkalsk undertrykkende samfunn. For eksempel ble rimming - oral-anal-sex - fremhevet som en revolusjonerende handling. New Yorks homoliv blomstret med klubber, barer og saunaer. Hiv og aids drepte mer enn mennesker.

Epidemien utraderte en hel subkultur. Ingen var uberørt. Hverdagen ble fylt av bisettelser. Slik beskriver France en scene fra noen år uti epidemien: "There was now a permanent line of wheelchairs outside the Village Nursing Home, where bony young men napped in the sun. The gay bars, which had been the teeming hub of gay society during his last visit, were now lifeless and ghostly places." 


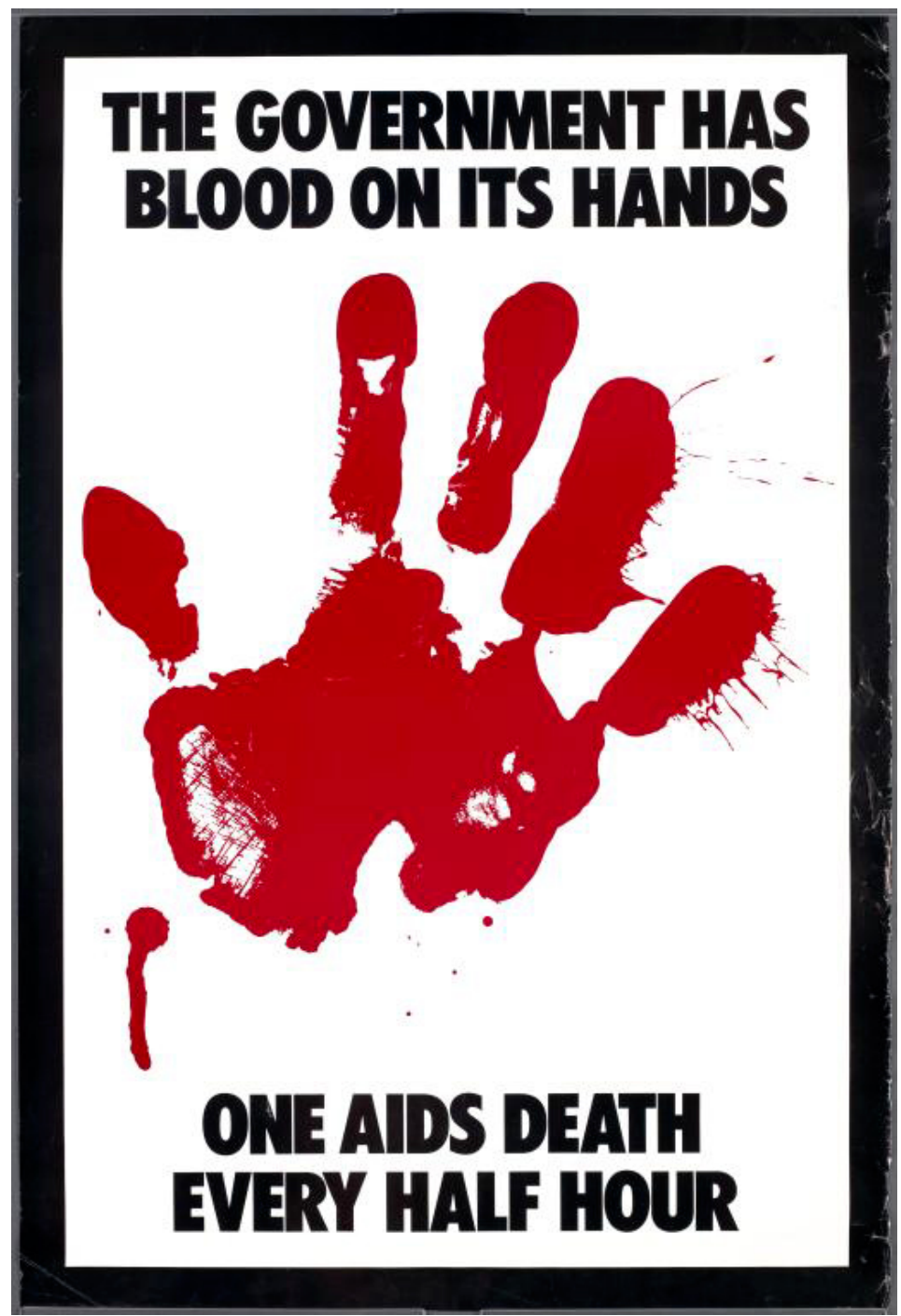

Epidemien samlet aktivister og kunstnere til felles aksjon som førte til en rekke kreative kampanjer. Gran Fury var et slikt kollektiv, og som Loring McAplin, medlem av gruppen, uttrykte det, var målet “... å kjempe like hardt for oppmerksomheten som Coca-Cola gjør det.” Blood on Its Hands-poster. Foto (C) Gran Fury

Hiv/aids-epidemien var også et kollektivt traume for homobevegelsen, og sykdommen infiltrerte seksualiteten gjennom å forsterke internalisert homofobi og skam over å ha ikkeheteroseksuell sex. For mange ble intimitet umulig, fordi smittefrykten var så stor: Kunne man dele tannbørste med kjæresten? Hva med et sår på leppen, kunne det smitte ved et kyss? France beskriver hvordan partneren til Staley opplevde det etter å ha avlagt en negativ test: "Learning he was healthy made him feel unreasonably lucky, like a man still standing after five rounds of Russian roulette. He withdrew physically, sometimes too afraid to even kiss. Staley's drives were similarly knotted up. The idea of sexual love was bound death with suicide and murder.”

\section{Aktivisme og mot}

Boken er også en historie om motstand og kamp, og om hvordan en sosial bevegelse kan trå inn når samfunnets institusjoner svikter. For eksempel var det hivaktivistene som fant opp konseptet “sikker sex". I 1983 utga aktivistene Richard Berkowitz og Michael Callen (1955-1993) pamfletten How to have sex in an epidemic: one approach, veiledet av legen Joseph Sonnabend. De var alle sentrale aktivister. Poenget deres var at det ikke var sex og kjærlighet mellom menn som var risikabelt, men det var hvordan man hadde sex. Det var ikke promiskuitet i seg selv som burde problematiseres, men sex uten kondom. Budskapet kom fra personer som selv var berørt. De kjente "språket” og visste hvor skoen trykket.

Denne kunnskapen kan overføres til skadereduserende forebyggingsarbeid generelt: Man 
må hjelpe mennesker der de er, ikke ut fra hvordan man selv mener at folk burde leve sine liv, men hjelpe folk til å treffe best mulig informerte valg. Ved å studere et fenomen på dets egne premisser blir det også tydelig at praksiser og handlemønstre ofte har andre forklaringer enn hva man først kan anta. Benny Henrikssons svenske etnografiske studie fra 1995, "Risk factor love", var sånn sett unik, ved at han oppsøkte mennene der de hadde sex, for eksempel på saunaene (3). Han viste at analsex uten kondom var en sterkt symbolmettet handling. Ved å droppe kondomet viste mennene intimitet og kjærlighet til partneren, altså en ganske annen forklaring enn at personer som droppet kondomet var "uansvarlige".

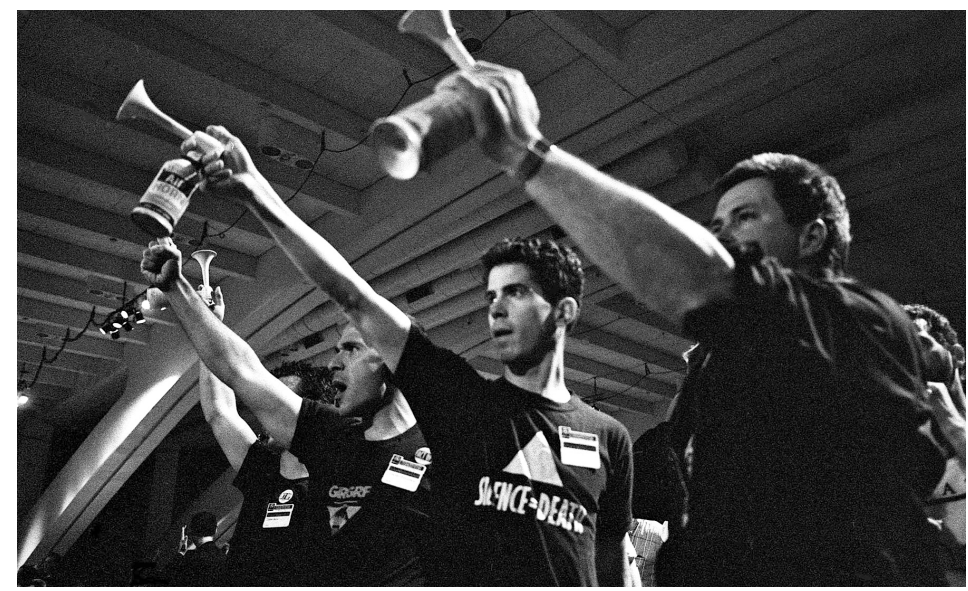

Mange aktivister boikottet aidskonferansen som fant sted i San Francisco i 1990 på grunn av innreiseforbudet for hivpositive til USA. ACT UP var til stede, deriblant Peter Staley (i midten), og avbrøt helseminister Louis Sullivans avsluttende innlegg. Foto @ Rick Gerharter

Gradvis ble hiv/aids-aktivismen profesjonalisert. For å få innflytelse skjønte aktivistene at de ikke bare måtte gå ut i gatene, men også inn i møterommene og skaffe seg plass rundt bordet hos Food and Drug Administration, National Institute of Health, i forskningsgrupper og i legemiddelfirmaene. Aktivistene måtte lære seg politikernes og forskernes språk, og de måtte forstå virologi, immunologi og statistikk.

Det er slående i hvilken grad historien om hiv/aids-aktivismen også er en tidlig fortelling om brukermedvirkning i forskning. Aktivistene lyktes med å portrettere seg selv som legitime representanter for forsøkspersonene - personer med aids. De krevde ikke bare medisiner til folket ("Drugs Into Bodies") og lavere priser på medikamentene, men også innflytelse på selve forskningsprosessen. For eksempel var det sterk motstand mot å teste AZT i en placeboarm og ikke gi alle med aids tilgang til medisinen. Den vanlige gangen i utprøvingen av legemidlet ble omgått, fase II-studien avbrutt på bakgrunn av lovende resultater og medikamentet tillatt på markedet i påvente av endelig godkjenning med bakgrunn i alvoret i situasjonen (også kalt "compassionate use”) (4).

Dideoxyinosine (ddI) ble innført gjennom en såkalt "parallellarm” for raskere å få medikamentet ut til personer med aids. Det betød at medikamentet omgikk både fase II- og III-utprøving.

Problemstillingen er like aktuell i dag, for eksempel ved utprøving av eksperimentell behandling av metastasert kreftsykdom: Hvordan forklarer du en pasient med en dødsdom at det er $50 \%$ sjanse for at du vil få sukkerpiller? Under utprøving av AZT gikk fors $\emptyset$ kspersonene langt i å sikre seg aktiv medisin: De lærte seg å smake forskjell på placebo og AZT, de blandet piller med andre studiedeltagere for å redusere risikoen for at de bare fikk placebo, de oppsøkte lokale laboratorier for å få analysert innholdet i kapslene.

Sosiologen Steven Epstein har i sin studie av hivepidemien, "Impure Science", vist i hvilken grad studieresultaters kredibilitet ikke bare avhang av studien og resultatene, men av hvorvidt forskjellige aktører lyktes med å presentere seg selv som troverdige representanter for eller fortolkere av forskningseksperimenter (5). Hiv/aids-epidemien var derfor også med på å endre hvordan biomedisinsk forskning utføres og særlig synet på å involvere brukere i forskningsprosessen. Frank Miedema, en av grunnleggerne av Science in Transition, en 
organisasjon som jobber for mer åpenhet i forskningspublisering og $ø$ kt brukerinvolvering, har sagt at hiv/aids-aktivistene fikk ham til å innse betydningen av brukerinvolvering $\mathrm{i}$ forskningen - for at forskerne kan stille de rette spørsmålene (6).

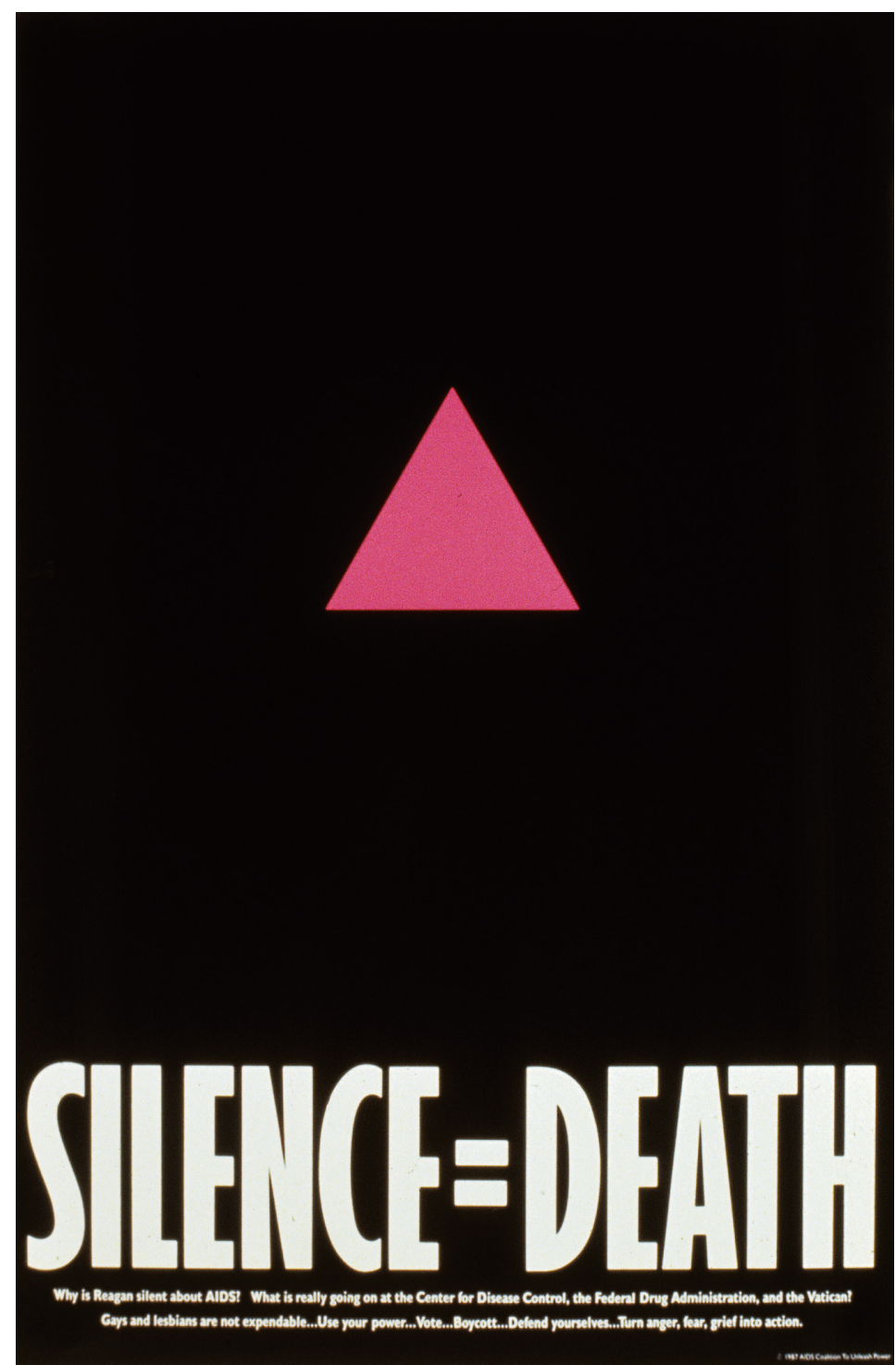

Ikonisk plakat fra 1987 som ble laget av Avram Finkelstein $i$ aktivistkollektivet Silence $=$ Death Kollektivet, som besto av flere grafiske designere, brukte visuelle virkemidler for å bryte tausheten omkring aids. Den rosa trekanten, som ble brukt til å merke homofile i konsentrasjonsleire under den annen verdenskrig, ble tatt $i$ bruk som et frigjørende symbol $i$ lhbt-bevegelsen $i$ 7o-årene. Foto: Silence = Death Project

Aktivistene stilte spørsmål ved gullstandarden innen medisinsk intervensjonsforskningdet randomiserte kontrollerte forsøket - og viste hvordan det i all medisinsk forskning gjøres en rekke normative vurderinger, for eksempel av hvordan studiegrupper settes sammen. På den måten lyktes aktivistene med å rokke ved statusen til det randomiserte kontrollerte forsøket som udiskutabel sannhet overførbar til den virkelige verden.

\section{Minoriteters felles kamp}

Hiv/aids-epidemien førte først til økt homofobi. Likevel, etter hvert gjorde den nok samfunnet mindre stigmatiserende med $ø$ kt toleranse for seksuelt mangfold. For eksempel har epidemien ført til at mediene friere kan omtale og diskutere kondombruk og ikkeheteroseksuell sex. Siden hivpositive sto frem og var så tydelige (også i Norge) fikk sykdommen et menneskelig ansikt. Slik sett kan hivepidemien, med historikeren Dagmar Herzogs ord, ikke ses som slutten på den seksuelle revolusjonen fra 6o- og 70-årene, men snarere at "sykdommens opptreden og kampen for å begrense den ble fulgt av fortsatt seksuell liberalisering" (1). 
Hiv/aids-epidemien er noe ganske annet i dag, i hvert fall i høyinntektsland med veletablerte helsevesen. Hiv er blitt en kronisk sykdom, hvor man har normale livsutsikter dersom man får effektiv behandling. Smitte fra mor til barn kan forhindres effektivt. Utdeling av rene sprøyter til personer som injiserer rusmidler, har gjort at hiv ikke lenger er en epidemi blant rusbrukere, i det minste ikke i Norge. Globalt sett rammer hivepidemien nå hardest afrikanske land sør for Sahara, hvor testing og tilgang på behandling fortsatt er et stort problem. Kvinner, barn, sexarbeidere og menn som har sex med menn er særlig rammet. I Øst-Europa og Sentral-Asia er epidemien økende, særlig blant personer som injiserer rusmidler, og det er mangel på skadereduserende, preventive tiltak. I flere deler av verden rammer altså epidemien fortsatt ulikt: Diskriminerte og stigmatiserte grupper er fremdeles mer utsatt. I Norge smittes drøyt 200 personer i året, og knapt halvparten er menn som har sex med menn (7).

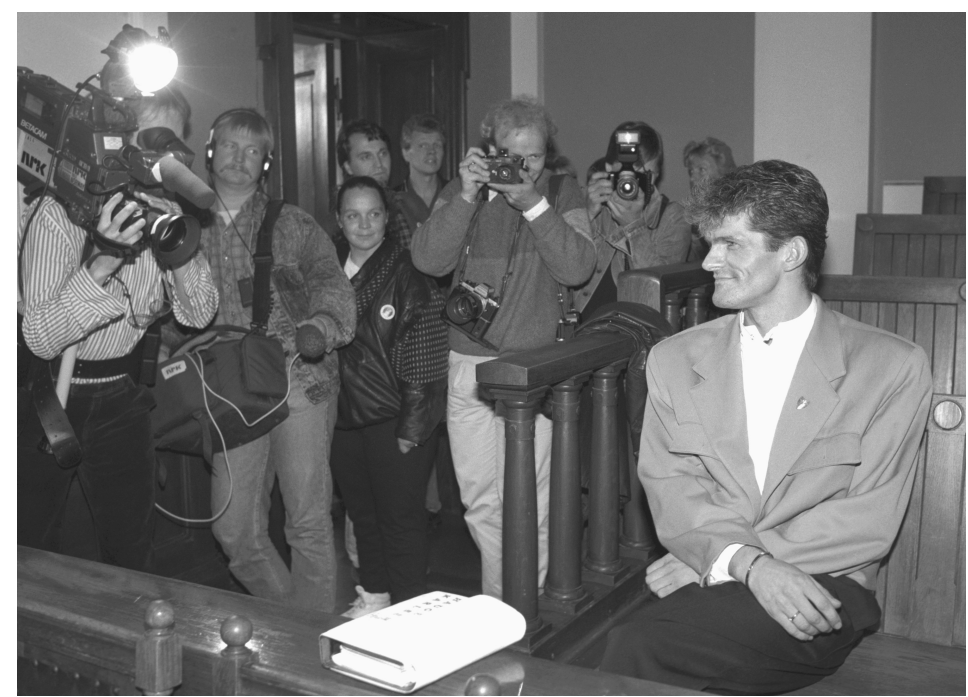

Henki Hauge Karlsen var hivpositiv og mistet jobben som bartender på grunn av smittefrykt. Han tok saken til retten sammen med sin advokat Tor Erling Staff og vant i Høyesterett i oktober 1988, og fikk dermed jobben tilbake. Dommen hadde stor prinsipiell betydning for hivsmittedes oppsigelsesvern. Noen uker senere døde Karlsen på Rikshospitalet. Han var den første hivpositive personen som sto frem i norsk offentlighet. Foto: Eystein Hanssen/NTB scanpix

Selv om hiv i Norge medisinsk sett er å betrakte som en infeksjon på linje med andre kroniske sykdommer, er den fortsatt omsluttet av skam. Den aktuelle diskusjonen om medikamentell hivforebygging - preeksponeringsprofylakse (PrEP) - har i en del homoseksuelle miljøer sett en tilbakevending mot moraliserende argumentasjon. Igjen er promiskuøs atferd blitt kritisert, idet at man har kritisert personer som ønsker å beskytte seg mot hiv, som "uansvarlige". Betegnelsen "Truvada-hore” ble født - etter medisinen Truvada som så langt er det eneste godkjente medikamentet til bruk for indikasjonen preeksponeringsprofylakse. FRI - foreningen for kjønns- og seksualitetsmangfold og Hiv Norge har fulgt opp med paneldebatter. Det viser at aktivistorganisasjonene fortsatt spiller en viktig rolle i forebyggingsarbeidet.

Historien om hiv og aids i USA viste at epidemien forsterket visse undertrykkende tendenser i samfunnet. For eksempel påpekte feministiske aktivister at fertile kvinner ofte ble ekskludert fra kliniske studier, av frykt for teratogene effekter av medikamentene, noe som medførte at spesifikke aidskomplikasjoner som man kun så hos kvinner, for eksempel bekkeninfeksjon, ikke ble anerkjent som aidsrelatert sykdom. Men historien om hiv/aidsaktivisme i USA viste at selv aktivistbevegelser kan bidra til å forsterke repressive mekanismer. I overgangen fra 8o- til go-årene påpekte aktivister innad i ACT UP at man i aktivistarbeidet prioriterte utfordringene til hvite, homofile menn på bekostning av kvinner og ikke-hvite.

Likevel viser 1980-årenes aktivister at sosiale bevegelser har potensial til å samles til én felles sak når det gjelder, for eksempel kvinnekamp, antirasisme og hivaktivisme. Vi så det sist $\mathrm{i}$ “Women's March" 21. januar i år, i forbindelse med at Donald Trump ble innsatt som 
president. Da gjorde lhbt (lesbiske, homofile, bifile og transperson)-organisasjonene felles sak med kvinnene. I den siste tiden har enkelte feminister fors $ø \mathrm{kt}$ å fremstille kampen for transkvinners rettigheter som i konflikt med et feministisk prosjekt. Det er det ingen grunn til, snarere bør vi sammen kjempe for rettighetene til alle kvinner.

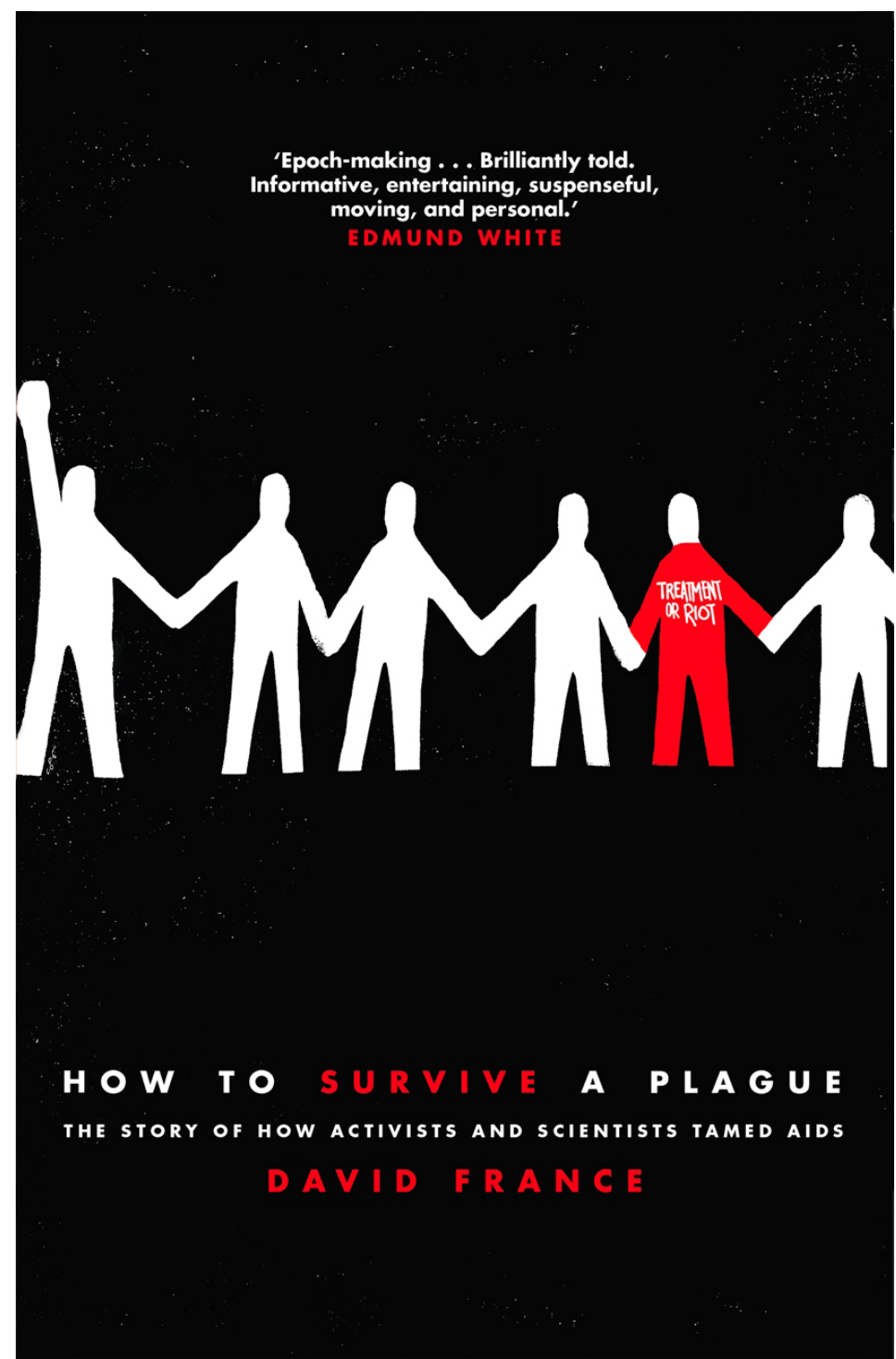

Aktuell bok: David France. How to survive a plague. London: Picador, 2016

Det er flere nylige eksempler på at høyreradikale krefter i dag har forsøkt å trykke lhbtsaken til brystet og bruke den for å fremme en innvandringsfiendtlig og islamofob politikk. De hevder at islam truer et samfunn med et bredt mangfold av seksualiteter og kjønnsuttrykk. Argumentasjonen er hul, den glemmer at muslimer ofte er offer for diskriminering i dagens samfunn, ikke minst skeive muslimer. Historien har vist at konservative krefter ikke sto på riktig side av hiv/aids-kampen. Hiv/aids-historien bør inspirere aktivistorganisasjonene også i dag til å stå skulder til skulder i arbeidet for minoriteters rettigheter.

\section{LITTERATUR:}

1. Herzog D. Sexuality in Europe: a twentieth-century history. Cambridge: Cambridge University Press, 2011:183.

2. Evensen SA, Gradmann C, Larsen Ø et al. Da hiv kom til Norge. Michael 2010; 7:12 - 157 .

3. Henriksson B. Risk factor love: homosexuality, sexual interaction and HIV-prevention. Göteborg: Göteborgs universitet, Institutionen för socialt arbete, 1995.

4. Jonsen AR, Stryker J. red. The social impact of AIDS in the United States. Washington, DC: National 
Academies Press (US), 1993.

5. Epstein S. Impure science - aids, activism, and the politics of knowledge. First. Los Angeles, LA: University of California Press, 1996.

6. Miedema F. To confront 21st century challenges, science must rethink its reward system. The Guardian. 12.5.2016.

https://www.theguardian.com/science/political-science/2016/may/12/to-confront-21st-century-challeng es-science-needs-to-rethink-its-reward-system (28.4.2017).

7. Folkehelseinstituttet. Hivsituasjonen i Norge per 31. desember 2016.

https://www.fhi.no/globalassets/dokumenterfiler/rapporter/hivarsoppgjor-2016.pdf(28.4.2017).

Publisert: 26. juni 2017. Tidsskr Nor Legeforen. DOI:10.4045/tidsskr.17.0398

(C) Tidsskrift for Den norske legeforening 2020. Lastet ned fra tidsskriftet.no 